\title{
Feasibility and Benefits of Rainwater Harvesting and Utilization as a Water Resource for Mining Industry in Mongolia
}

\author{
Enkhtaivan Batzaya ${ }^{1}$, Prof. Wang Rongchang ${ }^{2}$ \\ 1. UNEP-TONGJI Institute of Environmental Sciences and Sustainable Development (IESD) Tongji University, Shanghai, China. 200092 \\ 2. Institute of Biofilm Technology, Key Laboratory of Yangtze Aquatic Environment (MOE), State Key Laboratory of Pollution Control and \\ Resource Reuse, College of Environmental Science and Engineering, Tongji University, Shanghai, China. 200092
}

DOI: 10.29322/IJSRP.11.08.2021.p11682

http://dx.doi.org/10.29322/IJSRP.11.08.2021.p11682

\begin{abstract}
The main challenges and threats in the field of water supply of Mongolia are the use of water-consuming technologies, imperfection of technical and economic tools of water regulation and water distribution, global and regional climate changes. The relevance of research on water resources and water use problems is increasing all over the world in relation with the growth in economic activity and global climatic changes. Such studies are especially relevant for areas with limited water resources. Rainwater harvesting is an innovative technology used to collect rainwater from roofs and other above-ground surfaces for subsequent use.
\end{abstract}

Index Terms- Rainwater harvesting and utilization, mining industry, water resource, Mongolia

\section{INTRODUCTION}

$\mathrm{D}$ ue to climate changes, other internal and external factors (drying up of rivers and lakes, drainage of groundwater, drying up of pastures, intensification of desertification, changes in the amount and distribution of precipitation, increased frequency of droughts, etc.) affecting the water resources in Mongolia. In recent years increasing trend towards a decrease in the amount of water resources is gaining relevance. [1]

Our country compared to other countries in the world is rich in terms of natural resources, and mining resources account for a large share of state budget revenues. Mining sector's revenue accounted for a $1 / 4$ of the state budget, $80-86$ percent of last year's total exports, and about 17-20 percent of GDP. In the future, the mining sector is expected to grow rapidly and continue to contribute to the country's economic growth. [2]

Unfortunately, the mining industry has a very negative impact on the environment, which is one of the most emerging issues in the world today. As a result, countries around the world are pursuing and implementing environmental protection policies in conjunction with mining production and development policies [3]. However, in our country, it is not clear what kind of policy will be pursued and how to deal with the ecological damage caused by mining, especially in terms of water use. If water will be used in the mining sector without any policy or control, there will a danger that agricultural regions of Mongolia will be subject to desertification as a result of mining. Therefore, it is necessary to study the possibilities of improving water management in to reduce mining water usage.

The purpose of this paper is to determine feasibility of rainwater harvesting in Mongolian various regions and to utilize it in technical purposes of mining.

Results of this paper is mainly important as many mines in Mongolia consumes underground and on-ground water in its production process, whereas mining is one of the few industries that can consume water with lower quality than water can be consumed by human. Thus, in order to prevent or minimize environmental impact of mining activity, mines can partially meet demand of technical water using water harvested from rainfall. Ultimate outcome of such harvesting activities shall be provision of more drinkable quality water to population.

\section{MethodolOGY OF RAINWATER HARVESTING}

\section{Main steps of water harvesting}

Main components of water harvesting systems is shown in Figure 1 [4].

Catchment: An area of land that discharges some or all of its rainwater outside of the target area. The catchment area can be from a few square meters to several square kilometers. It can be any area where rain falls. For example, a roof or ground surface. Water transportation: A structure that directs the collected water into a storage tank.

Storage: The place where the runoff of water is stored from harvesting to use. Harvesting and storage facilities can be natural or man-made. They can be of different types, for example, a storage can be in the form of surface water bodies, underground water bodies, for example, wells, in the soil profile in the form of soil moisture, and also in underground aquifers. Almost any container made of metal, polyethylene, concrete, ceramics, clay, etc. [5]

Target site: a place where the collected water is used. In agricultural production, targets are plants or animals; in domestic use, they are a person or business and their needs. 


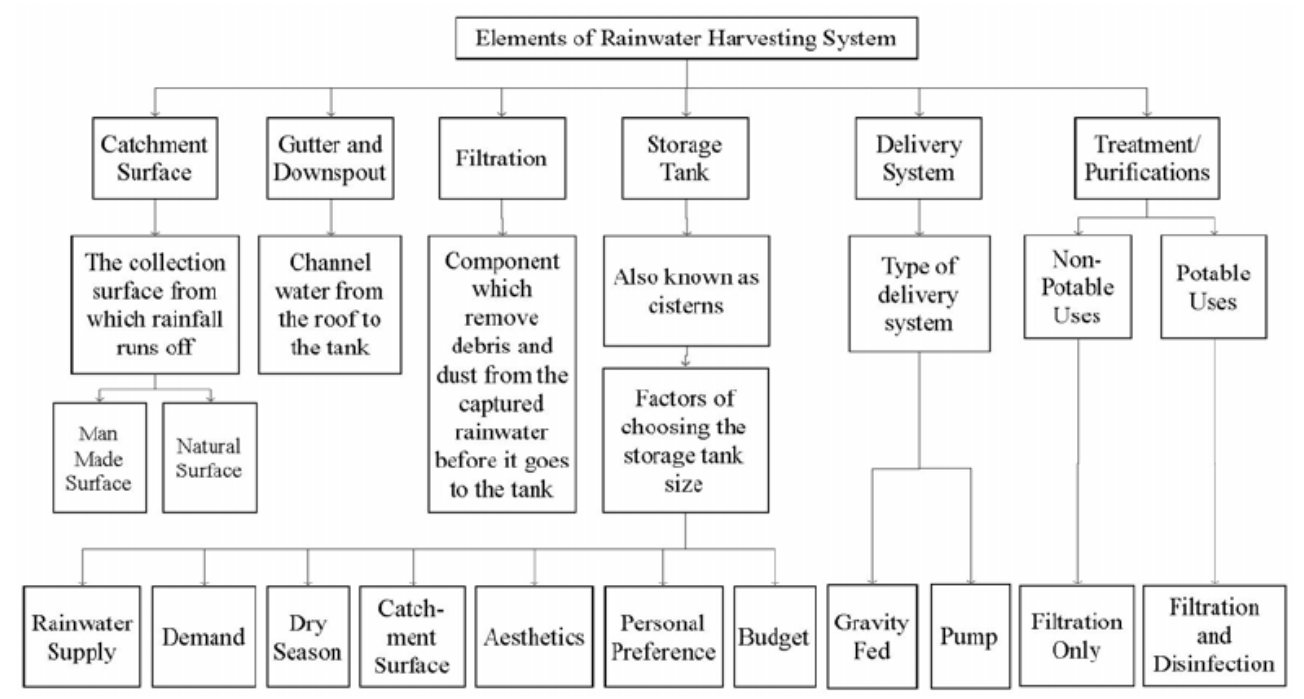

Figure 1: Elements of Rainwater Harvesting System

Climate change is projected to increase the variability and intensity of rainfall. Variability is of particular concern in regions close to the equator, where most developing countries are located. Changes in precipitation patterns will further exacerbate groundwater depletion caused by over-abstraction, land use change and population growth. [6]

Lack of adequate water supply during droughts and dry seasons can hinder economic development and lead to poor health and well-being. Having a convenient supply of water from a sludge store will reduce travel time to remote water sources and reduce the depletion of groundwater resources.

\section{METHODS OF RAINWATER HARVESTING}

Rainwater can be captured by using the rainwater harvesting system. Generally, rainwater harvesting system is the direct collection of rainwater from roofs and other purpose built catchments, the collection of sheet runoff from man-made ground or natural surface catchments and rock catchments for domestic, industry, agriculture and environment use. The systems can be categorized as small, medium and large scale [7]. Normally, the size of rainwater harvesting was based on the size of catchment area [8] . In scientific term, rainwater harvesting refers to collection and storage of rainwater and also other activities aimed at harvesting surface and groundwater, prevention of losses through evaporation and seepage and all other hydrological studies and engineering interventions, aimed at conservation and efficient utilization of the limited water endowment of physiographic unit as a watershed [9].

In most arid regions of the world, many different techniques have been developed. Most of them were intended for irrigation, some for collecting water for drinking needs of people and animals. The same methods may be called differently in different regions, and sometimes methods with the same names in practice are completely different. Water harvesting methods are classified in several ways, mainly based on the type of use or storage, but most often on the size of the catchment.

\section{Table 1: Methods of rainwater harvesting}

\section{Micro catchment}

This system collects surface runoff, as sheet flow over a short distance, from a small catchments area (around $1000 \mathrm{sq} \mathrm{m}$ ). Runoff water is usually applied to agriculture area where it is stored in root zone that can be used directly by the plants and also can be stored in small reservoir around the plant for later use.
On-farm system

On farm systems are designed and constructed at low-cost, making them easily replicable and
Rooftop system

Rooftops systems collect and store rainwater from roof of the houses or large buildings, greenhouses,

\section{Macro catchment}

Macro catchments and floodwater harvesting systems are characterized by having runoff water collected from a relatively large catchment. Often the catchment is a natural rangeland, the steppe, or a mountainous area. Generally, runoff capture is much lower than for microcatchments, ranging from a low percentage to $50 \%$ of the annual rainfall. Large macro-catchments systems in steppe areas are often called "floodwater-harvesting systems". According to the location of the target area, two types of macro-catchments exist: wadi-bed systems and off wadi systems.

Wadi-bed system Off-wadi system

In this system, the wadi The rainwater harvested in bed is used to store the run-off wadi systems is water, either on the applied outside the wadi surface by blocking the bed. Structures may be 
adaptable. It can be applied for any crop or any slope. They have higher runoff efficiency than macro-catchment systems and do not usually need water conveyance system. The most important landbased micro catchments or on-farm water harvesting systems in the dry areas of Wana are: trapezoidal bunds, contour ridges, small pits, small runoff basins, run-off strips, inter-row systems, meskat, countour-bench terraces. courtyards, and similar impermeable surfaces, including roads. Modern roofing materials and gutters, for example, allow the collection of clean water suitable for drinking and other domestic uses, especially in rural areas without tap water. Such systems provide a low cost water supply for humans and animals in remote areas. Although mainly used for domestic purposes, this technique also has agricultural uses. water flow, or in the soil profile by slowing down the flow and allowing it to infiltrate the soil. Examples are: small farm reservoirs, jessour etc. used to force the wadi water to leave its natural course and flow to nearby areas suitable for agriculture. Similar structures may also be used to collect rainwater from catchments outside the wadi bed. The following are the most important off-wadi techniques: waterspreading systems, large bunds, cisterns, tanks, hillside-runoff systems.
The harvesting of rainwater from roof surface area is increasingly being used as a technical solution to supplement the water supply of households and institutions, although this method has existed and has been used since antiquity. Roof covering is increasingly made from hard materials (metal or tiles). Thanks to this and the availability of metal and plastic parts for the water lines, the cost of implementing rainwater harvesting (RWH) by households has decreased.

The inclusion of RWH in domestic water supply in developing countries can make a significant contribution to development, as it saves money and time. Water storage facilities are a convenient and inexpensive source of water supply close to home. This significantly saves time that would otherwise be spent fetching water or standing in line at water points. This creates significant savings for households who sometimes have to buy bottled water or water from the market. In many settings, RWH reduces the risk of contact with waterborne pathogens, as it provides water of a better potable quality and high quality water for other domestic needs, such as hygiene, bathing, washing and washing.

\section{WATER RESOURCES FOR MINING INDUSTRY IN MONGOLIA}

\section{Mining industry in Mongolia}

Compared to many other countries, Mongolia's water resources are limited. The average annual rainfall ranges from 80 millimeters in the gobi region in the south to about 350 millimeters in the northern mountain areas. Seasonal variation in climatic conditions is strong, with 257 cloudless days in a year and with temperature ranging from -40 degrees Celsius $\left({ }^{\circ} \mathrm{C}\right)$ in winter (November-February) to $35^{\circ} \mathrm{C}$ in summer (July-September). The major challenge for water resources managers is to provide the services the population expects in terms of drinking water supply; support of economic activities; and environmental protection against droughts, floods, and water pollution.

Table 2: Main mines of Mongolia and their locations

$\begin{array}{ll}\text { Resource type } & \text { Name of Mine } \\ \text { Iron } & \text { Tamir Gol } \\ \text { Tumurtei } & \text { Aduunchuluun } \\ & \text { Chandgana Tal } \\ & \text { Eldev } \\ & \text { Khushuut } \\ & \text { Khuut } \\ & \text { Nariin Sukhait } \\ & \text { Ovoot Tolgoi } \\ & \text { Nuurst Khotgor } \\ & \text { Övdög Khudag } \\ & \text { Saikhan-Ovoo } \\ & \text { Tavan Tolgoi }\end{array}$

Province
Arkhangai
Selenge
Dornod
Khentii
Dornogovi
Khovd
Dornod
Ömnögovi
Ömnögovi
Uvs
Dundgovi
Bulgan
Ömnögovi

\author{
Location \\ Tüvshrüülekh sum \\ Choibalsan \\ Mörön sum \\ Dalanjargalan \\ Darvi sum \\ Matad sum \\ Gurvan tes sum \\ Bökhmörön \\ Bayanjargalan sum \\ Saikhan-Ovoo \\ Tsogttsetsii sum
}




$\begin{array}{clll} & \text { Tevshiin Govi } & \text { Dundgovi } & \text { Saintsagaan sum } \\ \text { Tsaidam Lake } & \text { Töv } & \text { Bayan sum } \\ \text { Tugrugnuur } & \text { Töv } & \\ & \text { Ulaan Ovoo } & \text { Selenge } & \text { Tüshig sum } \\ \text { Sharyn gol } & \text { Darkhan-Uul } & \text { Sharyngol sum } \\ & \text { Mogoin gol } & \text { Khövsgöl } & \text { Tsetserleg sum } \\ \text { Ovoot } & \text { Ömnögovi } & \\ \text { Copper } & \text { Oyuu Tolgoi } & \text { Ömnögovi } & \text { Khanbogd sum } \\ & \text { Erdenet } & \text { Orkhon } & \text { Erdenet } \\ & \text { Khökh-Adar } & \text { Bayan-Ölgii } & \text { Tolbo sum } \\ & \text { Tsagaan Suvarga } & \text { Dornogovi } & \text { Mandakh sum } \\ \text { Tavt } & \text { Bulgan } & \text { Teshig sum } \\ & \text { Boroo } & \text { Selenge } & \text { Bayangol sum / Mandal sum } \\ & \text { Gatsuurt } & \text { Selenge } & \text { Mandal sum } \\ & \text { Oyuu Tolgoi } & \text { Ömnögovi } & \text { Khanbogd sum } \\ & \text { Ulaan Uul } & \text { Bayan-Ölgii } & \text { Nogoonnuur sum } \\ & \text { Bürentsogt } & \text { Sükhbaatar } & \text { Mönkhkhaan sum } \\ & \text { Khovd Gol } & \text { Bayan-Ölgii } & \text { Tsengel sum }\end{array}$

Most of the mines are situated in Central and Southern provinces of Mongolia. Majority of them located in Dornogobi (160 special license), Selenge (118 special license), Khentii (102 special license), Umnugobi (91 special license), Dundgobi (84 special license).

Most of strategically important mines in Mongolia are coal mines and few mines of iron ore, gold and tungsten. Mines of Mongolia are situated in 17 aimaks of Mongolia, which shows that rainwater harvesting can be introduced in all aimaks.

\section{Water resources for mining in Mongolia}

Large mines are developing and have recently started operations in South Gobi, such as Oyu Tolgoi (copper), Tavan Tolgoi (coal) and Naryn sukhait (coal) along with (planned) value-adding industries which require the development of new water sources. The water resource system has to support this activity by providing, where possible, the water needed while satisfying competing water demands from the mining urbanization-herder nexus. The semi-arid area of Southern Gobi has no perennial rivers although dry river beds may become seasonal rivers post heavy showers. The sandy sediments of these dry rivers are recharged during such events providing a reliable shallow water source. Groundwater to a large extent was not much in use due to its salinity, but is now increasingly used to ensure a supply to the new mines. These deeper groundwater resources are fossil groundwater deposits which generally do not receive recharge.

Future water demand in Galba-Uush-Doloodiin Govi Water Basin in 2021 is projected to increase by 350 percent, 720 percent and 912 percent in the low, medium and high economic development scenarios, respectively. The high increase in water demand is driven by the newly developed mines, namely Oyu Tolgoi, Tavan Tolgoi and Tsagaan Suvarga. Future water demand in the Umard-Goviin-Guveet-Khalkhiin Dundad Tal water basin in 2021 is projected to increase by 20 percent, 50 percent and 120 percent in the low, medium and high economic development scenarios respectively. The main driver for this increase is predominantly an increase in water demand from mining. Livestock currently has the highest water demand in this basin but this is not expected to change significantly. In order to increase the value-add of Mongolia's mining products, the Government has decided to construct the "Sainshand" industrial complex where coke, metal, coal, copper smelting and construction material industries will be located. The water demand for the development of this industrial complex will require additional groundwater resources, which is included in the high development scenario for 2021. Investigations are underway to find suitable resources although these may not be found near the urban center.

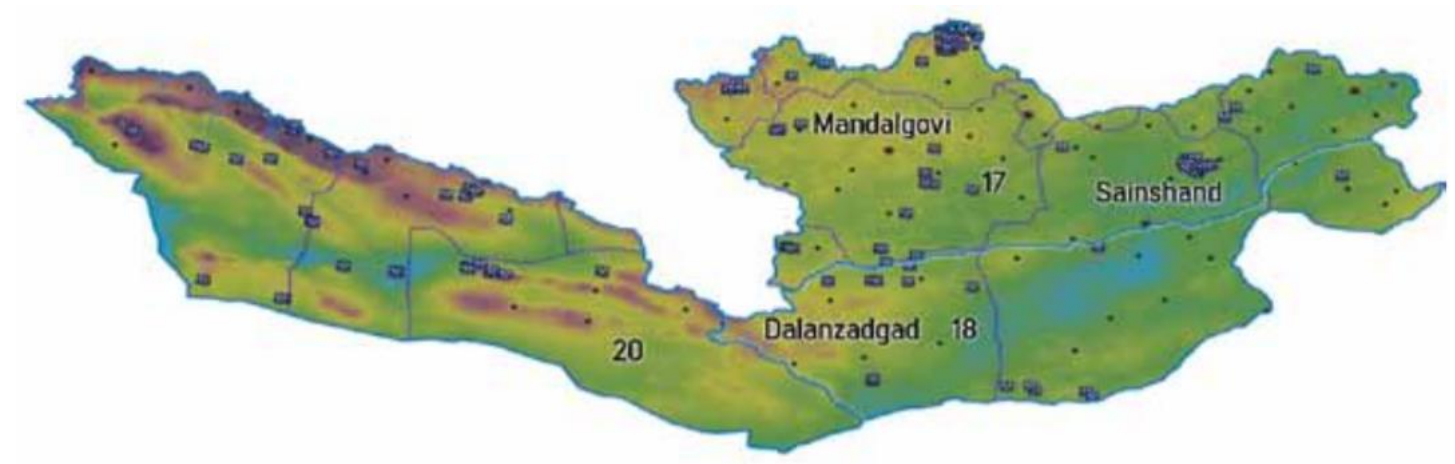

Figure 2: The Three Water Basins and Mining Locations in the Southern Gobi [3] 


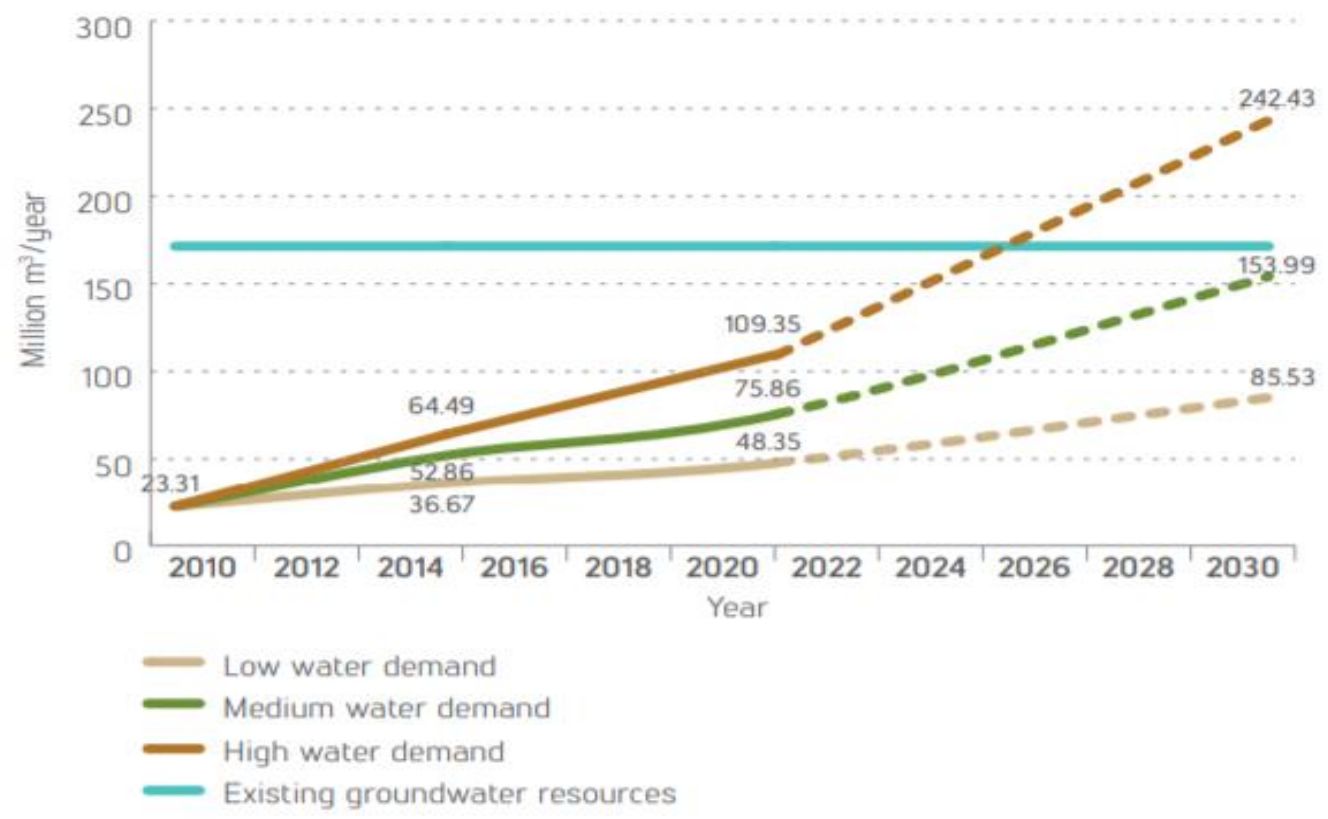

Figure 3: The water demand projections and existing groundwater resources for the Southern Gobi [3]

Assuming the groundwater resource availability remains at the current level, it can be estimated that water demand will exceed available water resources between 2021 and 2030 under the high water demand growth scenario. Under the low and medium scenarios, existing groundwater resources are expected to meet demand. However, it needs to be stressed that while the overall water resources and demand balances at the regional level of the Southern Gobi do not show a gap for the low and medium water demand growth scenarios, high water risks are expected at the local level including quantity and quality. In some cases, however, water can be or needs to be sourced over long distances. For example, for the mine Oyu Tolgoi the distance to the nearest groundwater source, Gunii Hooloi, is about $50 \mathrm{~km}$. In addition, whether the abstraction of groundwater is from deep aquifers or from shallow aquifers will also have differential impact on other users and the environment. Thus, water risks are highly localized and the impacts can differ strongly between stakeholders (groups) in the same area. It needs to be noted that the data situation in the Southern Gobi is difficult, thus estimates need to be treated with care. Existing reports on water supply and demand projections, such as the World Bank assessment (2015) and the assessment undertaken by McKinsey provide varying estimates.

\section{Rainwater in Mongolia}

As for preliminary research, following two variables will be analyzed in this study: temperature and rainfall statistics. Temperature is important, because rainwater harvesting can be performed only in warm seasons and therefore such activities cannot be run during winter times. Rainfall statistics is required to determine most humid areas of Mongolia and may act as cut-off factor for implementing rainwater harvesting activities in specific provinces.

\section{Temperature}

Mean temperature recorded in Mongolia ranges from $11.37^{\circ} \mathrm{C}$ to $15.23^{\circ} \mathrm{C}$ during rainfall period. Most warm regions of Mongolia is Central region with minimum temperature of $3.86^{\circ} \mathrm{C}$ and up to $22.02{ }^{\circ} \mathrm{C}$. Coldest region is Western region, where temperature ranges between $0.93{ }^{\circ} \mathrm{C}$ up to $18.24{ }^{\circ} \mathrm{C}$. As shown in figure below, most warm aimaks are Dornogovi, Omnogovi, Dundgovi, Dornod and Govisumber.

Table 3: Average monthly temperature during rainfall period, ${ }^{\circ} \mathrm{C}$

\begin{tabular}{|c|c|c|c|c|c|c|}
\hline Aimak & May & June & July & August & September & October \\
\hline Bayan-Ulgii & 9.84 & 16.31 & 18.17 & 15.72 & 9.94 & 1.88 \\
\hline Govi-Altai & 7.60 & 13.72 & 16.13 & 14.33 & 8.12 & 0.12 \\
\hline Zavkhan & 8.39 & 14.80 & 16.63 & 14.27 & 8.09 & -0.95 \\
\hline Uvs & 11.63 & 19.02 & 20.81 & 18.10 & 11.24 & 1.98 \\
\hline Khovd & 10.97 & 16.64 & 18.86 & 16.60 & 10.87 & 2.61 \\
\hline Bayankhongor & 10.11 & 16.07 & 18.67 & 16.52 & 10.53 & 1.01 \\
\hline Bulgan & 9.85 & 15.68 & 18.43 & 15.40 & 9.49 & 0.25 \\
\hline Orkhon & 9.72 & 15.41 & 18.13 & 15.28 & 9.85 & 1.37 \\
\hline
\end{tabular}




\begin{tabular}{|c|c|c|c|c|c|c|}
\hline Uvunkhangai & 10.12 & 15.59 & 17.76 & 16.16 & 11.01 & 2.84 \\
\hline Arkhangai & 10.67 & 16.14 & 18.15 & 16.31 & 10.68 & 2.58 \\
\hline Khovsgol & 7.84 & 13.91 & 16.26 & 14.13 & 8.32 & -0.79 \\
\hline Govisumber & 12.33 & 18.45 & 20.88 & 18.65 & 12.75 & 2.70 \\
\hline Darkhan-Uul & 12.19 & 18.82 & 21.39 & 18.38 & 12.05 & 2.89 \\
\hline Dornogovi & 15.62 & 21.74 & 25.01 & 22.80 & 16.19 & 6.15 \\
\hline Dundgovi & 11.99 & 18.49 & 21.20 & 19.05 & 12.87 & 3.27 \\
\hline Omnogovi & 16.03 & 21.69 & 24.55 & 22.58 & 16.54 & 7.48 \\
\hline Selenge & 11.80 & 18.49 & 20.96 & 17.82 & 11.49 & 1.93 \\
\hline Sukhbaatar & 11.75 & 18.07 & 19.88 & 17.58 & 11.39 & 1.85 \\
\hline Tuv & 8.92 & 15.36 & 17.92 & 15.55 & 9.94 & 0.52 \\
\hline Dornod & 12.78 & 19.38 & 22.00 & 19.91 & 13.28 & 2.87 \\
\hline Khentii & 12.16 & 18.53 & 21.13 & 19.05 & 12.65 & 2.49 \\
\hline
\end{tabular}

\section{Rainfall}

Details of monthly rainfall and monthly variations of precipitation are obtained from National Statistics Office of Mongolia. It can be seen that most of precipitation is observed in Khangai region and Eastern regions, including some aimaks in
Western region. Precipitation in southern aimaks is relatively low, compared to others. From precipitation data shown in Table 4, for example during the rainfall period total of 342 liters of water can be harvested from 1 square meter. In souther aimaks, in average 111.85 liters of rainwater can be harvested from $1 \mathrm{~m}^{2}$.

Table 4: Total monthly precipitation during rainfall period, $\mathbf{m m}$

\begin{tabular}{|c|c|c|c|c|c|c|}
\hline Aimak & May & June & July & August & September & October \\
\hline Bayan-Ulgii & 14.09 & 25.01 & 26.88 & 25.25 & 8.21 & 3.31 \\
\hline Govi-Altai & 16.86 & 38.97 & 35.53 & 33.12 & 13.91 & 9.52 \\
\hline Zavkhan & 15.47 & 33.20 & 57.85 & 48.55 & 20.95 & 10.14 \\
\hline Uvs & 8.19 & 17.49 & 25.71 & 27.50 & 10.78 & 11.55 \\
\hline Khovd & 24.93 & 41.25 & 55.01 & 54.54 & 20.11 & 10.61 \\
\hline Bayankhongor & 16.19 & 35.58 & 49.91 & 47.79 & 17.19 & 5.44 \\
\hline Bulgan & 22.17 & 58.21 & 93.82 & 70.27 & 29.08 & 9.63 \\
\hline Orkhon & 29.29 & 70.89 & 99.98 & 93.48 & 34.94 & 13.59 \\
\hline Uvunkhangai & 13.92 & 40.01 & 83.97 & 57.32 & 16.14 & 7.01 \\
\hline Arkhangai & 22.55 & 42.79 & 81.23 & 73.84 & 24.25 & 12.11 \\
\hline Khovsgol & 19.35 & 52.09 & 69.55 & 72.68 & 27.44 & 11.88 \\
\hline Govisumber & 6.37 & 25.27 & 41.55 & 26.72 & 12.23 & 7.72 \\
\hline Darkhan-Uul & 30.93 & 60.28 & 61.76 & 100.99 & 36.61 & 14.23 \\
\hline Dornogovi & 12.09 & 21.65 & 29.48 & 27.91 & 13.45 & 6.43 \\
\hline Dundgovi & 6.48 & 17.42 & 38.74 & 30.28 & 8.17 & 4.21 \\
\hline Omnogovi & 11.13 & 21.28 & 33.15 & 22.62 & 16.67 & 6.37 \\
\hline Selenge & 26.76 & 48.94 & 63.20 & 79.65 & 34.83 & 9.50 \\
\hline Sukhbaatar & 16.98 & 46.69 & 74.47 & 76.53 & 27.09 & 9.05 \\
\hline Tuv & 23.67 & 50.66 & 75.81 & 55.79 & 20.01 & 9.86 \\
\hline Dornod & 15.73 & 40.81 & 58.07 & 53.95 & 23.14 & 9.54 \\
\hline Khentii & 19.03 & 48.25 & 63.26 & 49.22 & 21.33 & 8.53 \\
\hline
\end{tabular}




\section{RAINWATER HARVESTING METHOD IN MONGOLIA}

\section{Proposed rainwater harvesting structures}

We choose concrete pond rainwater harvesting method as method with highest water harvesting capacity. Rooftop systems can catch relatively small amount of water and harvesting amount is limited only to roof area. On the other side wadi-bed system is suitable only for agricultural water usage. Thus system with minimal water drainage indicator is most suitable for technological process.

Due to the features of rainfall, water harvested from rain is proportional to its harvesting structure area. This relationship can be expressed by following formula:

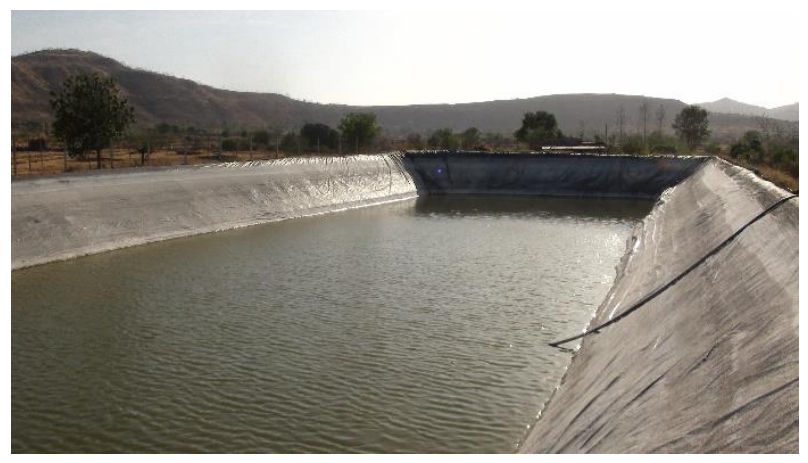

Equation 1. RWH main formula

Total rainwater to be harvested(tons)

$$
\begin{aligned}
& =\frac{\text { Precipitation }(\text { in } \mathrm{mm})}{1000} \\
& \times \text { Area of structure }(\text { in } \mathrm{m} 2)
\end{aligned}
$$

Even though many facilities around the world using rooftop rainwater harvesting technology, its best to use open-space harvesting method, as its more suitable for meeting mine's technical water demand. Rainwater harvesting structures are proposed to be made of concrete or coated with geotextile to prevent water leakage out of the pond. Also, we suggest to calcite for softening water during centralized drinking water treatment for mine workers.

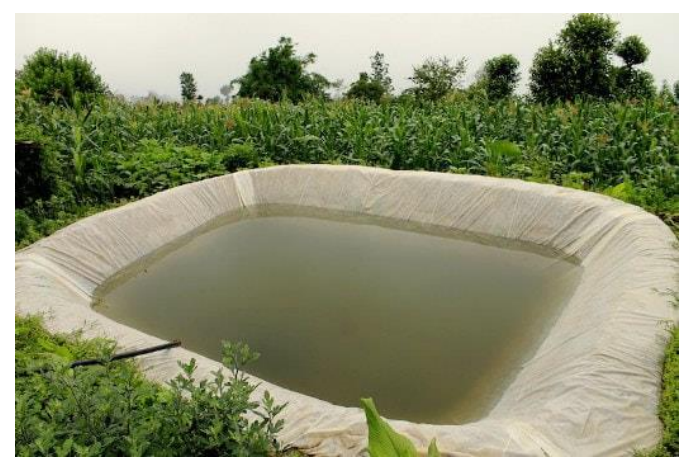

Figure 4. Concrete ponds for rainwater harvesting

Below table shows amount of water that can be harvested from ponds with different size. For example pond with size $400 \times 500 \mathrm{~m}$ can harvest during rainfall period 22245 tons of rainwater in Omnogovi aimak and 68432 tons of rainwater in
Orkhon aimak. However this amount of water is cannot meet demands of typical average mine, where water consumption can vary from 300000 to 3 million tons of water per year [10].

Table 5: Relationship between harvested rainwater during rainfall period and area of structure

\begin{tabular}{ccccc}
\hline Size & $\mathbf{1 0 0 x 2 0 0 ~} \mathbf{~}$ & $\mathbf{2 0 0 x 3 0 0 ~} \mathbf{~}$ & $\mathbf{3 0 0 x} \mathbf{4 0 0} \mathbf{~ m}$ & $\mathbf{4 0 0 \times 5 0 0 ~} \mathbf{~}$ \\
\hline Area & $20,000 \mathrm{~m}^{2}$ & $60,000 \mathrm{~m}^{2}$ & $120,000 \mathrm{~m}^{2}$ & $200,000 \mathrm{~m}^{2}$ \\
Bayan-Ulgii & $2,055.1$ & $6,165.2$ & $12,330.4$ & $20,550.7$ \\
Uvs & $2,024.6$ & $6,073.7$ & $12,147.4$ & $20,245.7$ \\
Khovd & $4,129.0$ & $12,387.1$ & $24,774.2$ & $41,290.3$ \\
Orkhon & $6,843.3$ & $20,529.8$ & $41,059.7$ & $68,432.8$ \\
Uvunkhangai & $4,367.4$ & $13,102.3$ & $26,204.6$ & $43,674.3$ \\
Arkhangai & $5,135.2$ & $15,405.7$ & $30,811.3$ & $51,352.2$ \\
Khovsgol & $5,059.6$ & $15,178.7$ & $30,357.3$ & $60,958.5$ \\
Darkhan-Uul & $6,095.8$ & $18,287.5$ & $36,575.0$ & $22,203.5$ \\
Dornogovi & $2,220.3$ & $6,661.0$ & $13,322.1$ & $21,058.1$ \\
Dundgovi & $2,105.8$ & $6,317.4$ & $12,634.9$ & $22,245.5$ \\
Omnogovi & $2,224.6$ & $6,673.7$ & $13,347.3$ & $52,574.9$ \\
Selenge & $5,257.5$ & $15,772.5$ & $31,545.0$ & $50,163.3$ \\
Sukhbaatar & $5,016.3$ & $15,049.0$ & $30,098.0$ & $47,157.3$ \\
Tuv & $4,715.7$ & $14,147.2$ & $28,294.4$ & $40,248.4$ \\
Dornod & $4,024.8$ & $12,074.5$ & $24,149.1$ & $41,923.3$ \\
Khentii & $4,192.3$ & $12,577.0$ & $25,154.0$ & \\
\hline
\end{tabular}


Example: Harvested water in Khentii province is $12577 \mathrm{~m} 3$. Which is calculated as follows: take total precipitation in $\mathrm{mm}$ in Khentii province $(209.62 \mathrm{~mm})$, multiply by corresponding area in top row $(60.000 \mathrm{~m} 2)$ and divide by 1000 to convert liters to $\mathrm{m} 3$. According to recent studies, comfortable water consumption per person per day is estimated around 100 liters/day [11]. Suggesting that rainwater will be consumed only during warm months or rainfall period, harvesting pond with size of $400 \times 500$ meters (total area $200000 \mathrm{~m}^{2}$ ) can provide water for 1483 people for 150 days in Omnogovi aimak and 4562 people in Orkhon aimak.

Table 6: Number of people that can be supplied with harvested rainwater

\begin{tabular}{ccccc}
\hline Size & $\mathbf{1 0 0 x 2 0 0 ~} \mathbf{~}$ & $\mathbf{2 0 0 x 3 0 0 ~}$ & $\mathbf{3 0 0 x} \mathbf{4 0 0} \mathbf{~ m}$ & $\mathbf{4 0 0 \times 5 0 0 ~} \mathbf{~}$ \\
\hline Area & $20,000 \mathrm{~m}^{2}$ & $60,000 \mathrm{~m}^{2}$ & $120,000 \mathrm{~m}^{2}$ & $200,000 \mathrm{~m}^{2}$ \\
Bayan-Ulgii & 137 & 411 & 822 & 1,370 \\
Uvs & 135 & 405 & 810 & 1,350 \\
Khovd & 275 & 826 & 1,652 & 2,753 \\
Orkhon & 456 & 1,369 & 2,737 & 4,562 \\
Uvunkhangai & 291 & 873 & 1,747 & 2,912 \\
Arkhangai & 342 & 1,027 & 2,054 & 3,423 \\
Khovsgol & 337 & 1,012 & 2,024 & 3,373 \\
Darkhan-Uul & 406 & 1,219 & 2,438 & 4,064 \\
Dornogovi & 148 & 444 & 888 & 1,480 \\
Dundgovi & 140 & 421 & 842 & 1,404 \\
Omnogovi & 148 & 445 & 890 & 1,483 \\
Selenge & 350 & 1,051 & 2,103 & 3,505 \\
Sukhbaatar & 334 & 1,003 & 2,007 & 3,344 \\
Tuv & 314 & 943 & 1,886 & 3,144 \\
Dornod & 268 & 805 & 1,610 & 2,683 \\
Khentii & 279 & 838 & 1,677 & 2,795 \\
\hline
\end{tabular}

Note: water consumption per person is taken as 100 liters per day, and number of days to be supplied by rainwater is taken as 150 days. Multiply $12577 \mathrm{~m} 3$ (from previous table) by 1000 to convert to liters and divide by 100 liters to obtain person-days. Then divide by 150 days to obtain suppliable days.

IV.2 Economic benefits of using rainwater in mining

Table 7: Water payment in various locations

\begin{tabular}{|c|c|c|c|c|c|}
\hline Province & River basin & $\begin{array}{c}\text { Ecological value } \\
\text { of } 1 \mathbf{~ m}^{3} \\
\text { underground } \\
\text { water, USD }\end{array}$ & $\begin{array}{c}\text { Payment } \\
\text { ratio } \\
{[12]}\end{array}$ & $\begin{array}{l}\text { Water usage } \\
\text { coefficient for } \\
\text { mining } \\
\text { purposes [13] }\end{array}$ & $\begin{array}{c}\text { Payment per } \\
1 \mathrm{~m}^{3} \text { water, } \\
\text { USD }\end{array}$ \\
\hline $\begin{array}{c}\text { Omnogovi } \\
\text { /Nariin } \\
\text { Sukhait/ }\end{array}$ & $\begin{array}{l}\text { Galba-Oosh Dolood } \\
\text { Gobi basin }\end{array}$ & 1.40 & $20 \%$ & 1.2 & 0.33 \\
\hline $\begin{array}{c}\text { Omnogovi } \\
\text { /Tavantolgoi/ }\end{array}$ & $\begin{array}{l}\text { Altai-Uvur govi } \\
\text { basin }\end{array}$ & 1.55 & $20 \%$ & 1.4 & 0.43 \\
\hline
\end{tabular}

Example: $1241.2 \mathrm{m3}$ equals to $1.55 \times 20 \% \times 1.4$

According to resolutions of Government of Mongolia, ecological value in various basins of Omnogovi province are rated differently. For example, $1 \mathrm{~m}^{3}$ underground water near Nariin Sukhait valued at 1.4 USD, whereas near Tavantolgoi at 1.55 USD. Payment for water resources shall be calculated as follows: $1.4 \times 20 \%$. Then that value shall be multiplied by water coefficient depending on type of economic activity. Thus: $1.4 \times 20 \% \times 1.2=0.33$ USD per $1 \mathrm{~m}^{3}$. 
Table 8: Volume of harvestable water in Omnogovi /Nariin Sukhait/

\begin{tabular}{cccc}
\hline $\begin{array}{c}\text { Size of } \\
\text { structure, } \mathbf{m}\end{array}$ & $\begin{array}{c}\text { Harvested } \\
\text { rainwater, } \mathbf{m} 3\end{array}$ & $\begin{array}{c}\text { Payment if used underground water } \\
\text { resources (full year), USD }\end{array}$ & $\begin{array}{c}\text { Payment if used underground water } \\
\text { resources (part-year), USD }\end{array}$ \\
\hline $\mathbf{5 0 0 \times 6 0 0}$ & $33,368.3$ & 11228.6 & 5614.3 \\
\hline
\end{tabular}

Example: $11228.6=33368.3$ (from Table 4-4) $\times 0.33$ (from Table 4-3)

Let's assume that mine exploits harvesting structure with size 500x600 meters. Then such structure can harvest in total $33368.3 \mathrm{~m}^{3}$ of rainwater during rainfall period. If mine will exploit such amount of water from underground resources, then it will be subject to 11228.6 USD payment. If mine will supply part of its water demand by rainwater, it will pay only half of that payment -5614.3 USD.

Table 9: Investment cost for RWH structure in Omnogovi /Nariin Sukhait/

\begin{tabular}{cccc}
\hline $\begin{array}{c}\text { Area of groundwork, } \\
\mathbf{m 2}\end{array}$ & $\begin{array}{c}\text { Volume of groundwork, } \\
\mathbf{~ m 3}\end{array}$ & $\begin{array}{c}\text { Total groundwork cost, } \\
\text { USD }\end{array}$ & $\begin{array}{c}\text { Investment cost for RWH structure, } \\
\text { USD }\end{array}$ \\
\hline $\mathbf{2 0 , 0 0 0}$ & 14,000 & 1336.1 & 2004.2 \\
$\mathbf{6 0 , 0 0 0}$ & 42,000 & 4008.4 & 6012.6 \\
$\mathbf{1 2 0 , 0 0 0}$ & 84,000 & 8016.8 & 12025.2 \\
$\mathbf{2 0 0 , 0 0 0}$ & 140,000 & 13361.4 & 20042.1 \\
$\mathbf{3 0 0 , 0 0 0}$ & 210,000 & 20042.1 & 30063.1 \\
\hline
\end{tabular}

Note: Assume that one excavator productivity is $2 \mathrm{~m} 3$ per minute or $120 \mathrm{~m} 3$ per hour (Caterpillar CAT-320DL, 16 liters of diesel fuel per machine hour). Cost of 1 liter of diesel fuel is taken as 0.71 USD. Investment cost is taken as 1.5 of ground works.

Above table summarized total investment cost for RWH structure. Total groundworks are estimated at $210.000 \mathrm{~m} 3$. Total groundwork cost are calculated basing on basic petroleum price and investment costs are calculated based on multiplier coefficient. For structure with size of total investment cost are estimated at at 30036 USD.

Table 10: Cost comparison for RWH structure in Omnogovi /Nariin Sukhait/

\begin{tabular}{ccc}
\hline Case of 500x600 & Cost without RWH, USD & Cost with RWH, USD \\
\hline Year 1 & 11228.2 & 35677.45 \\
Year 2 & 11228.2 & 5614.3 \\
Year 3 & 11228.2 & 5614.3 \\
Year 4 & 11228.2 & 5614.3 \\
Year 5 & 11228.2 & 5614.3 \\
Year 6 & 11228.2 & 5614.3 \\
Year 7 & 11228.2 & 5614.3 \\
Year 8 & 11228.2 & 5614.3 \\
Year 9 & 11228.2 & 5614.3 \\
Year 10 & 11228.2 & 5614.3 \\
Total & 112286 & 86206.17 \\
\hline
\end{tabular}

We compared costs of rainwater harvesting structure and groundwater usage payments. Without RWH structure, mine will pay 11228.2 USD per year on technical water needs, in total 112286 USD in 10 years. In case of RWH structure, in 10 years payments would be only 86206.17 USD. Needless to say, that usage of groundwater resources has many indirect negative effects on environment. If mine will supply technical water demands solely by rainwater, then cost will be limited only by at maximum 35088 USD. As for cost, with RWH, cost per $1 \mathrm{~m} 3$ will be 0.33 USD, whereas for case with RWH, cost will be 0.25 USD.

\section{Environment and social benefits}

If we take into account that more than $50 \%$ of the average daily water requirement (100 liters per person) - is the nondrinking part, which can be replaced with rainwater harvested in the way described above, it can be suggested that technical rainwater collection systems provide significant cost savings. Initial investment, taking into account the offers on the market, seems to be very moderate.

In order to effectively implement and develop water harvesting projects, relevant bodies firstly shall meet with potential beneficiaries, discuss with them, and demonstrate the 
willingness and potential to work for their benefit. If the technologies offered do meet their needs, it is possible to start planning activities together, starting with improving knowledge and developing technologies. It is important that project initiators must know that such projects will bring real value to them. Project implementers can often ignore the indirect benefits when conducting feasibility studies for water harvesting projects, but their importance needs to be understood. These benefits include stopping land degradation, combating desertification, providing animals with drinking water, reducing migration to cities, minimizing social problems, improving the living standards of herder families, and the stability and security of rural life.

\section{DISCUSSION}

The Concept for Sustainable Development of Mongolia until 2030 contains the most important directions of state policy in the field of protection and rational use of water resources. These include: improving the system of state management of water relations, including the development of a unified plan for water resources management; meeting the needs of the population and economic facilities in water resources; protection and rational use of water resources.

The creation of the infrastructure of the mining enterprise and environmental pollution put enormous pressure on the traditional nomadic way of life of the local population - the negative impact of extreme weather conditions (dzud), changes in the structure of migrations, lack of jobs, social services and other changes for the population displaced to somoni centers. Water scarcity and expected long-term water shortages are of greatest concern. Problems with water supply, watering of pastures, a decrease in the number of wells, and a deterioration in the quality of water in wells do not go unnoticed by the government of Mongolia: special programs are being introduced to provide water to rangelands, trying to transfer pastoralists to a semi-nomadic way of farming, introducing various warm pens for livestock and procurement crops, i.e., eventually go to farming. All this can lead to the fact that the Mongols can change their centuries-old way of life from nomadic to semi-nomadic or sedentary, and this will be a larger-scale problem.

\section{CONCLUSIONS}

In order to prevent or minimize environmental impact of mining activity, mines can partially meet demand of technical water using water harvested from rainfall. The use of rainwater as an alternative source of water supply for mining industry in Mongolia has been proven on the positive side. The introduction of collection and accumulation systems for the use of rainwater in the water supply systems of urban and rural settlements is an advanced technology that ensures the implementation of the principle of rational use of water resources. The introduction of this technology would be especially valuable in Mongolia, where the volumes of surface and underground unpolluted waters are constantly decreasing and the ecological imbalance caused by such management of natural resources is becoming more and more distinct.

\section{REFERENCES}

[1] [1] ADB, "OVERVIEW OF MONGOLIA'S WATER RESOURCES SYSTEM AND MANAGEMENT," ADB, Mandaluyong, 2020.

[2] [2] National Statistics Office of Mongolia, "Statistical Bulletin," NSO, Ulaanbaatar, 2020.

[3] [3] Ministry of Environment of Mongolia, "INTEGRATED WATER RESOURCES MANAGEMENT IN MONGOLIA,” Ulaanbaatar, 2017.

[4] [4] Department of Environment and Conservation, "MANAGING URBAN STORMWATER," Department of Environment and Conservation NSW, Sydney, 2006.

[5] [5] A. \&. N. S. \&. S. A. Che-Ani, "Rainwater Harvesting as an Alternative Water Supply in the Future," European Journal of Scientific Research, 2009.

[6] [6] A. George \& Angelakis, "History of water cisterns: Legacies and lessons" 1916-1940, 2013

[7] [7] G. John, "Contributions Relating to Rainwater Harvesting"World Commission on Dams Secretariat, Geneve, 1999.

[8] [8] T. Mohammed ба M. Noor, "Study on Potential Uses of Rainwater Harvesting in Urban Areas" Rainwater Utilization Colloquium, 2007.

[9] [9] A. David, "Rainwater Harvesting As An Adaptation to Climate Change," Journal of Current Science, 46-59, 2003.

[10] [10] A. J. Gunson, "Quantifying, reducing, and improving mine water use," University of British Columbia, Vancouver, 2013.

[11] [11] World Health Organization, "How much water is needed," WHO, Leicestershire, 2013.

[12] [12] Government of Mongolia, "Annex 1 to Government Resolution No. 302 of 2011," Ulaanbaatar, 2011

[13] [13] Government of Mongolia, "Annex to Government Resolution No. 327 of 2013," Ulaanbaatar, 2013.

[14] [14] V. Liew, "Which Lag Selection Criteria Should We Employ?," Economics Bulletin, 1-9, 2014.

[15] [15] Tamil Nadu praised as role model for Rainwater Harvesting, 2011.

[16] [16] V. Aich, S. Liersch, T. Vetter, J. Andersson, E. Müller ба F. Hattermann, "Climate or land use? - Attribution of changes in river flooding in the Sahel zone," Water, 2796-2820, 2015.

[17] [17] O. Amogu, M. Esteves, J.-P. Vandervaere, M. Malam Abdou, G. Panthou, J.-L. Rajot, K. Souley Yéro, S. Boubkraoui, J.-M. Lapetite бa N. Dessay, "Runoff evolution due to land-use change in a small Sahelian catchment," Hydrological Science, 78-95, 2015.

[18] [18] P. Tamagnone, G. Massazza, A. Pezzoli ба M. Rosso, "Hydrology of the Sirba River: Updating and Analysis of Discharge Time Series," 2019.

[19] [19] V. Bigi, A. Pezzoli ба M. Rosso, "Past and Future Precipitation Trend Analysis for the City of Niamey," Climate, 2018.

[20] [20] J. Tabor, "Improving crop yields in the Sahel by means of waterharvesting," Arid Environment, 83-106, 1995.

[21] [21] Z. Malley, B. Kayombo, T. Willcocks бa P. Mtakwa, "An indigenous, sustainable and profitable soil, water and nutrient conservation system in Tanzania for sloping land," Soil Tillage , 2004.

[22] [22] S. Walker, M. Tsubo ба M. Hensley, "Quantifying risk for water harvesting under semi-arid conditions," Agricultural Water Management, 94$107,2005$.

[23] [23] A. Fewkes, "The modelling and testing of a rainwater catchment system in the UK," Nottingham Trent University, Nottingham, 2004.

[24] [24] G. G. M. C. F. C. F. Forzieri, "A methodology for the preselection of suitable sites for surface and underground small dams in arid areas: A case study in the region of Kidal," Physics and Chemistry of the Earth, 74-85, 2008 .

[25] [25] S. Gebrekristos, "Understanding catchment processes and hydrological modelling in the Abay/Upper Blue Nile Basin," Delft University of Technology, 2015.

[26] [26] E. B. D. M. M. Ghisi, "Rainwater tank capacity and potential for potable water savings by using rainwater in the residential sector of southeastern Brazil," Building and Environment, 1654-1666, 2007.

[27] [27] S. M. C. Ghosh, "Assessing hydrological impacts of climate change : Modeling techniques and challenges," The Open Hydrology Journa, 115-121, 2010. 
[28] [28] J. D. M. M. G. J. P. Gregory, "Analysis of double-ring infiltration techniques and development of a simple automatic water delivery system," Applied Turfgrass Science, 2005.

[29] [29] K. D. J. S. K. Gupta, "Estimation of water harvesting potential for a semiarid area using GIS and remote sensing," IAHS Publications-Series of Proceedings and Reports-Intern Assoc Hydrological Sciences, 1997.

[30] [30] Z. S. S. H. S. Hassan, "Application of SDSM and LARS-WG for simulating and downscaling of rainfall and temperature," Theoretical and Applied Climatology, 243-257, 2014

[31] [31] N. Ibraimo, "Rainwater harvesting: Management strategies in semi-arid areas," University of Pretoria, 2011.

[32] [32] A. K. S. P. N. S. R. P. N. 2. Kadam, "Identifying potential rainwater harvesting sites of a semi-arid, basaltic region of Western India, Using SCSCN method," Water Resource Management, 2537-2554, 2012.

\section{AUTHORS}

First Author - Batzaya Enkhtaivan, Graduate student, Tongji

University, UN Environment-Tongji Institute of Environment for
Sustainable Development (IESD): College of Environmental Science and Engineering; Email: Ezaya.0912@gmail.com, Phone No: +86 18521358250, Address: 1239 Siping Road, Shanghai 200092, China.

Second Author - Professor Wang Rongchang (Ph.D.) Biological wastewater treatment, water pollution control. Key Laboratory of Yangtze Aquatic Environment (MOE), State Key Laboratory of Pollution Control and Resource Reuse, College of Environmental Science and Engineering, Tongji University, Shanghai, 200092, China. Tel: 008621-65986919, Email:

wangrongchang@tongji.edu.cn.

Correspondence Author - Professor Wang Rongchang, Tel:

008621-65986919, Email: wangrongchang@tongji.edu.cn. 